\title{
Role of lncRNAs in GI Cancer
}

\author{
Murali Krishna ${ }^{*}$, Anju Mullath ${ }^{2}$ \\ ${ }^{1}$ Military Hospital, Palampur, India \\ ${ }^{2}$ DNB Gastroenterology Lakeshore Hospital and Research Centre, Cochin, India \\ Email:*murali276@yahoo.com
}

How to cite this paper: Krishna, M. and Mullath, A. (2018) Role of lncRNAs in GI Cancer. Journal of Cancer Therapy, 9, 281-298.

https://doi.org/10.4236/jct.2018.93026

Received: February 17, 2018

Accepted: March 16, 2018

Published: March 19, 2018

Copyright $\odot 2018$ by authors and Scientific Research Publishing Inc. This work is licensed under the Creative Commons Attribution International License (CC BY 4.0).

http://creativecommons.org/licenses/by/4.0/

\section{(c) (i) Open Access}

\begin{abstract}
IncRNAs forms a part of the non coding part of human genome. This term denotes specific non coding RNAs with nucleotide length more than 200. They have been shown to affect various physiological and pathological processes within the human body. Of interest is their role in malignant transformation in several cancers. In this review, the role of lncRNAs in GI cancers namely pancreatic cancer, gastric cancer, hepatocellular cancer and colorectal cancer have been explained in brief. These lncRNAs have shown to be useful as a marker for detection and prognosis of various malignancies. They also have shown to have therapeutic potential. Various relevant lncRNAs in each section has also been mentioned.
\end{abstract}

\section{Keywords}

lncRNA, Cancer, Pancreatic, Gastric, Hepatocellular, Colorectal

\section{Introduction}

The human genome continues to baffle both scientists and doctors alike. It has been known for a long time that out of the total genome of $3000 \mathrm{Mb}$ only $1 \%$ codes for all the proteins [1]. The rest which was earlier thought to be junk DNA is showing to have many previously unknown functions. One among these is the long non coding RNA.

The genome code from DNA is transcripted into RNA in its entirety, but only part of this RNA is translated into proteins. The rest constitutes what is called as non coding RNAs. These include ribosomal RNAs, ribozymes, transfer RNAs, small nuclear RNAs, small nucleolar RNAs and telomere associated RNAs [2] [3]. Non coding RNAs with length more than $200 \mathrm{nt}$ have been termed as long non coding RNAs. Recent studies using microarray technologies have shown that lncRNAs play an important role in several aspects of malignancies. In this 
review, we will be looking at the specific actions of lncRNAs and its role in GI cancers, namely pancreatic cancer, gastric cancer, hepatocellular cancer and colorectal cancer.

\section{Materials and Methods}

A literature search was done on PubMed database to check for review article and clinical trials relating to "lncRNA" and "cancer" in the last 5 years. Out of the total 878 articles, non human studies were excluded. The search was further narrowed down to include only full text articles and finally 49 articles, related to GI cancers in this review, were selected. This included 20 articles of gastric cancer, 15 articles of colorectal cancer, 12 articles of pancreatic cancer and 2 articles of hepatocellular cancer (Figure 1).

\section{Classification and Function of lncRNAs}

There are many different criteria for classification of lncRNA. One of the earliest was based on genomic location by which it was classified into sense, antisense, intronic, intergenic and bidirectional [4]. Another classification is based on targeting mechanism-signal, decoy, guide and scaffold [5]. With the ongoing research and latest discoveries the list of lncRNAs is evergrowing. However, the classification system results in several overlapping and omissions [6] [7]. An ideal classification system is yet to happen.
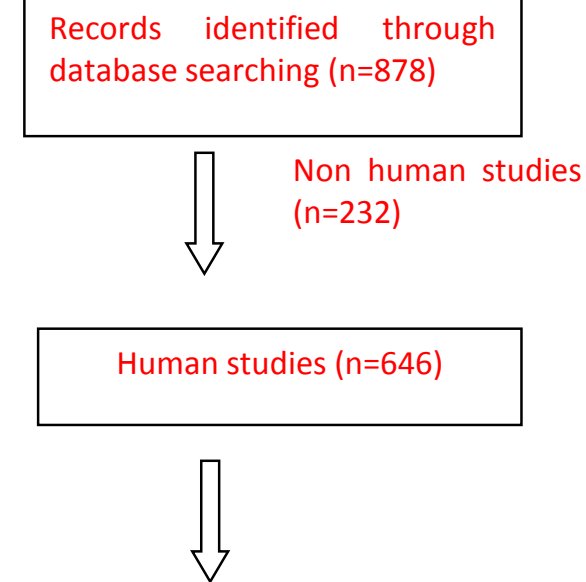

Full text articles $(n=283)$

$$
\sqrt{\begin{array}{l}
\text { Non GI } \\
(n=234)
\end{array}}
$$

Gl cancer articles $(n=49)$

Figure 1. Flowchart of study selection. 
IncRNAs are known to affect diverse processes within the cell. An idea of function can be made based on its subcellular localization [8]. It can be subnuclear, cytoplasmic or both [9] [10]. IncRNA in nuclear position usually affect nuclear function via transcriptional or epigenetic modifications [11] [12] [13] and cytoplasmic lncRNA modulates mRNA stability and translation [13] [14]. The three known mechanisms by which lncRNA affect the cellular processes are epigenetic regulation, transcriptional regulation and post transcriptional regulation [15] [16] [17] [18] [19].

\section{Role of IncRNAs in GI Cancers}

\subsection{Pancreatic Cancer}

Pancreatic cancer (PC) is one of the leading causes for cancer related deaths in US and the 5 year survival rate is around 5\% [20]. The key to management of PC is early diagnosis and hence it is imperative to have better diagnostic and prognostic markers. The currently used markers include CA19-9, CA242 and CEA [21]. These markers have the down side of not being specific to PC. IncRNA provides a unique opportunity in early diagnosis of PC without invasive testing. The potential lnc markers with relation to PC include HOTTIP-005, XLOC_006390 and RP11-567G11.1 [22]. Detection of salivary levels of HOTAIR and PVT1 provide an attractive non invasive technique towards detection of PC [23]. Also few lncRNAs have shown to correlate with the clinical characteristics and prognosis of patients. For example increase in levels of HOTAIR has shown to be a negative prognostic factor [24]. Other similar prognostic markers include AFAP1-AS1, BC008363 and MALAT-1 [22] [25] [26].

LncRNAs are breaking new grounds in treatment of PC. Gemcitabine is one of the commonly used drug in therapy of PC. However, few patients have shown to have resistance against this therapy. Study of such patients using microarray have shown that few of IncRNAs are upregulated in these patients. Levels of HOTTIP, PVT1 and MALAT-1 were found to be raised [27] [28] [29]. Therapeutics based on regulating the levels of these lncRNAs could prove vital in making chemotherapy more effective. Another novel therapeutic technique is based on lncRNA H19. Currently in phase 1/2a, BC-819 has been used in patients of unresectable PC. BC-819 is a double stranded DNA plasmid and is injected under CT/USG guidance [30]. A list of lncRNAs found to important in pancreatic cancer is given in the table below (Table 1). Out of these lncRNAs HOTAIR and MALAT-1 has been found to be more important with relation to pancreatic cancer.

\subsection{Gastric Cancer}

Of all malignancies, gastric cancer is the fourth most common cancer worldwide. It is also the third most leading cause of deaths caused due to cancer [51]. As in all cancers, early detection has a good prognosis for gastric cancer also because the 5 year mortality for advanced cancer is only $30 \%-50 \%$ [52]. Of late 
Table 1. IncRNAs in pancreatic cancer.

\begin{tabular}{|c|c|c|c|c|}
\hline LncRNA & $\begin{array}{l}\text { Genomic } \\
\text { location }\end{array}$ & Function & Potential targets & References \\
\hline HOTAIR & $12 \mathrm{q} 13.13$ & $\begin{array}{c}\text { Cancer cell } \\
\text { invasion, proliferation, } \\
\text { progression }\end{array}$ & PRC2, GDF15 & $\begin{array}{c}{[24][31][32]} \\
{[33][34]}\end{array}$ \\
\hline HOTTIP & $7 q 15.2$ & $\begin{array}{c}\text { Cancer cell proliferation, } \\
\text { inhibit apoptosis }\end{array}$ & $\begin{array}{l}\text { AURKA, WDR5, } \\
\text { HOXA10, HOXB2 }\end{array}$ & [35] [36] \\
\hline MALAT-1 & $11 \mathrm{q} 13.1$ & $\begin{array}{l}\text { Regulate cell cycle, growth, } \\
\text { migration }\end{array}$ & $\begin{array}{l}\text { Sox2, E-cadherin, } \\
\text { N-cadherin, VEGF }\end{array}$ & [29] [37] [38] \\
\hline ENST00000480739 & $12 \mathrm{q} 13.3$ & $\begin{array}{l}\text { Regulate invasion and } \\
\text { migration }\end{array}$ & OS-9, HIF-1 & [39] \\
\hline AFAP1-AS1 & $4 \mathrm{p} 16.1$ & $\begin{array}{c}\text { Regulate cell } \\
\text { proliferation, migration } \\
\text { and invasion }\end{array}$ & - & [40] [41] \\
\hline BC008363 & $5 q 21.2$ & - & - & [25] \\
\hline H19 & $11 \mathrm{q} 15.5$ & - & Let-7, HMGA2 & $\begin{array}{l}{[38][42][43]} \\
{[44][45][46]}\end{array}$ \\
\hline PVT1 & $8 \mathrm{q} 24.21$ & - & - & [47] [48] \\
\hline GAS5 & $1 \mathrm{q} 25.1$ & Inhibit cell proliferation & CDK6 & [49] \\
\hline AF339813 & $13 q 32$ & $\begin{array}{l}\text { Apoptosis, regulate } \\
\text { cell cycle }\end{array}$ & $\begin{array}{l}\text { NUF2, CDK1, } \\
\text { CDK4/CDK6 }\end{array}$ & [50] \\
\hline
\end{tabular}

numerous studies have shown that non coding RNAs play an important part in proliferation, migration and invasion in gastric cancer.

The role of lncRNAs in the pathogenesis of tumor is exactly not known. They are thought to influence the final gene product by several mechanisms like DNA methylation and chromatin modification [53]. LncRNA HOXA11-AS was found to be overexpressed in gastric cancer by doing a microarray profile. Also increased level of HOXA11-AS was associated with poor prognosis [54]. Another finding by $\mathrm{Xu}$ et al. was that low level of FENDRR was associated with poor prognosis and that elevated levels reduce cancer metastasis [55]. A list of lncRNAs found to important in gastric cancer is given in the table below (Table 2). Like many other malignancies, HOTAIR has shown to be important in gastric cancer also. Studies have shown that specific variation in HOTAIR is associated with increased risk for specific cancers. A study by Mulong et al. [56] showed that SNP rs4759314 was associated with significantly increased risk of gastric cancer. This could act as a potential bio marker to predict increased susceptibility to cancer.

\subsection{Hepatocellular Carcinoma}

Hepatocellular carcinoma (HCC) is the second leading cause mortality due to cancer in the world [72] and the incidence rate is on an increase. Delay in diagnosis is the major factor affecting mortality. It is imperative that newer biomarkers be found for early diagnosis and prognostic assessment of HCC. An exact understanding of pathogenesis of the tumor will help to evolve new 
Table 2. lncRNAs in gastric cancer.

\begin{tabular}{|c|c|c|c|}
\hline $\operatorname{lncRNA}$ & Function & Potential target & Reference \\
\hline LINC00673 & $\begin{array}{c}\text { Proliferation, invasion and } \\
\text { metastasis }\end{array}$ & KLF2, LATS2 & {$[57]$} \\
\hline SNHG5 & Proliferation and migration & miR-32 & [58] \\
\hline LincRNAFEZF1-AS1 & $\begin{array}{l}\text { Proliferation, tumor growth } \\
\text { and apoptosis }\end{array}$ & $\mathrm{p} 21$ & [59] \\
\hline PVT1 & $\begin{array}{l}\text { Proliferation and } \\
\text { metastasis }\end{array}$ & FOXM1 & [60] \\
\hline lncRNA-GHET1 & Proliferation & $\mathrm{c}-\mathrm{Myc}$ & [61] \\
\hline TINCR & Proliferation and apoptosis & KLF2 & [62] \\
\hline ANRIL & Proliferation & miR-99a/miR-449a & [63] \\
\hline LincHOTAIR & Invasion and metastasis & miR34a & [64] \\
\hline GAPLINC & Proliferation and invasion & $\operatorname{miR} 211-3 p$ & [65] \\
\hline FENDRR & Migration and invasion & FN1 & [55] \\
\hline H19 & $\begin{array}{l}\text { Proliferation, migration and } \\
\text { metastasis }\end{array}$ & ISM1 & [38] \\
\hline FER1L4 & Proliferation and cell cycle & PTEN & [66] [67] \\
\hline GAS5 & Cell cycle & YBX1 & [68] \\
\hline nc886 & Proliferation & FOS, MYC & [69] \\
\hline HOXA11-AS & $\begin{array}{l}\text { Proliferation, migration, } \\
\text { invasion and apoptosis }\end{array}$ & EZH2, LSD1 & [54] \\
\hline GClnc1 & $\begin{array}{l}\text { Proliferation, migration and } \\
\text { invasion }\end{array}$ & WDR5, KAT2A & [70] \\
\hline ВC032469 & Proliferation & hTERT & [71] \\
\hline
\end{tabular}

treatment and diagnostic methods. IncRNAs has emerged as an interesting prospect for same. It has been found that epigenetic changes are more common in HCC than in other cancers [73]. Also lncRNA is one of the main culprits responsible for these epigenetic alterations.

Major HCC related lncRNAs are H19, HOTAIR, HULC and HOTTIP. They have been shown to be involved in various functions like proliferation, apoptosis, invasion and metastasis. $\mathrm{H} 19$ has shown to act like an oncogene and enhances the tumorigenic potential of HCC cells [74]. However, there are other studies showing that $\mathrm{H} 19$ acts as a tumor suppressor [45]. Without any doubt H19 has shown to be closely involved with HCC progression and also it has a linear correlation with AFP levels [75]. It can be used as a marker in addition to AFP levels.

Another marker shown promise is HOTAIR. It regulates silencing of HOX locus [31] and has been found to be overexpressed in HCC tissues [76] [77]. The specific expression of these lncRNAs allow for its detection in bodily fluid. An example is elevated levels of HULC in HCC patients as compared to control [78]. A list of lncRNAs found to be important in hepatocellular cancer is given in the table below (Table 3). Another lncRNA which has been found to be more 
Table 3. lncRNAs in hepatocellular cancer.

\begin{tabular}{ccccc}
\hline LncRNA & $\begin{array}{c}\text { Genomic } \\
\text { location }\end{array}$ & Function & Potential target & References \\
\hline H19 & $11 \mathrm{p} 15.5$ & $\begin{array}{c}\text { Proliferation and inhibit } \\
\text { migration }\end{array}$ & IGF2, AFB1 & {$[74][80]$} \\
HOTAIR & $12 \mathrm{q} 13.13$ & Proliferation & $\begin{array}{c}\text { PRC2, H3K27, P16, } \\
\text { P14 }\end{array}$ & {$[77]$} \\
HOTTIP & $7 \mathrm{p} 15.2$ & Proliferation & HOXA13 & {$[35]$} \\
HULC & $6 \mathrm{p} 24.3$ & Proliferation & PPARA, ACSL1, & {$[81]$} \\
MALAT1 & $11 \mathrm{q} 13.1$ & Invasion & Sp1/3, SRSF1 & {$[82]$} \\
MVIH & $10 \mathrm{q} 22-\mathrm{q} 23$ & $\begin{array}{c}\text { Proliferation, invasion } \\
\text { and metastasis }\end{array}$ & miR-199a & {$[83]$} \\
MEG3 & $14 \mathrm{q} 32.2$ & $\begin{array}{c}\text { Inhibit cell growth } \\
\text { Proliferation and cell } \\
\text { cycle progression }\end{array}$ & miR-374a, miR-545 & {$[85][86]$} \\
\hline
\end{tabular}

specific for HCC is LINC01225. In a study conducted by Wang et al. [79], this specific lncRNA was found to be overexpressed in cases of HCC and was also confirmed by in vivo animal studies. LINC01225 acts by increasing level of epidermal growth factor receptor (EGFR) and its level can be measured in serum, thus making it an attractive future biomarker.

\subsection{Colorectal Cancer}

Colorectal carcinoma (CRC) has been known to be affected by epigenetic and genetic mutations as classically described in the adenoma-carcinoma sequence by Fearon and Vogelstein [87]. The adenoma carcinoma sequence describes the orderly progression of normal epithelium to carcinoma. Each step is associated with specific mutations involving specific pathways. Each of these pathways has shown to have specific lncRNAs associated with it. The first lncRNA shown to have a role in CRC was endogenous $\mathrm{H} 19$ gene reported by Hibi et al. [88].

IncRNA may be the future biomarkers for screening, diagnosis, prognosis and also therapy for CRC [89]. One of the promising methods for susceptibility screening is to check for single nucleotide polymorphism (SNP) in lncRNA region. For example lncRNA CCAT2 maps to genome 8q24. A SNP rs6983267 is related to this genome and is linked to CRC oncogenesis, progression and prognosis [90].

Another role for lncRNA is in the early diagnosis of CRC. The modality of choice at present is periodic screening by colonoscopy which is both invasive and time consuming. A non invasive blood test could be helpful in easy screening of CRC. IncRNA (LIT1/KCNQ1OT1) was found to be increased in tumor samples as compared to normal tissue [91]. Other potential biomarkers include elevated level of hypomethylated CAHM in plasma and elevated CCAT1 in fecal and blood samples [92].

lncRNA is also being looked upon to be a prognostic marker. lincRNA-p21, ncRAN and Loc285194 has shown to be useful for this purpose [93] [94] [95]. 
Table 4. IncRNAs in colorectal cancer.

\begin{tabular}{|c|c|c|c|}
\hline $\operatorname{lncRNA}$ & Location & Function & Reference \\
\hline CCAL & $3 q 29$ & Suppress AP- $2 \alpha$ & [99] \\
\hline CCAT1 & $8 \mathrm{q} 24.21$ & - & [100] [101] [102] \\
\hline CCAT1-L & $8 \mathrm{q} 24.21$ & Regulate chromatin interaction & {$[103]$} \\
\hline CCAT2 & $8 \mathrm{q} 24.21$ & Upregulate Wnt signalling & [90] \\
\hline CRNDE & $16 \mathrm{q} 12.2$ & Respond to EGFR signalling & {$[104][105]$} \\
\hline E2F4 antisense & $16 \mathrm{q} 21-22$ & Reduces level of E2F4 & [106] \\
\hline HOTAIR & $12 \mathrm{q} 13.13$ & Correlate to PRC2 function & [34] \\
\hline HULC & $6 \mathrm{p} 24.3$ & - & [107] \\
\hline KCNQ1OT1/LIT1 & $11 \mathrm{p} 15.5$ & Participates in mesenchymal transition & {$[91][108]$} \\
\hline $\operatorname{lncRNA-ATB}$ & $14 \mathrm{q} 11.2$ & Activated by TGF- $\beta$ & [109] \\
\hline MALAT1 & $11 \mathrm{q} 13.1$ & Promotes mesenchymal transition & {$[37]$} \\
\hline ncNRFR & $1 \mathrm{p} 13.2$ & Inhibit function of let-7 & [110] \\
\hline PCAT1 & $8 \mathrm{q} 24.21$ & - & [111] \\
\hline PVT1 & $8 \mathrm{q} 24$ & Antiapoptotic activity & {$[112]$} \\
\hline uc.73A & $2 \mathrm{q} 22.3$ & Decrease apoptosis & [113] \\
\hline CUDR & $19 \mathrm{p} 13.12$ & - & {$[114]$} \\
\hline BANCR & $9 \mathrm{q} 21$ & Suppress cell proliferation & [115] \\
\hline CAHM & $6 \mathrm{q} 26$ & - & {$[92]$} \\
\hline LncRNA-LET & $15 \mathrm{q} 24.1$ & Contributes to metastasis & [116] \\
\hline LincRNA-p21 & $6 \mathrm{p} 21.2$ & Transcriptional co activator of p53 & {$[93]$} \\
\hline Loc285194 & $3 q 13.31$ & Inhibit tumor cell growth & [95] [117] \\
\hline MEG3 & $14 \mathrm{q} 32.2$ & Induces accumulation of $\mathrm{p} 53$ & [118] [119] \\
\hline ncRAN & $17 \mathrm{q} 25.1$ & - & {$[94]$} \\
\hline PTENP1 & $9 \mathrm{p} 13.3$ & Regulates cellular level of PTEN & {$[120]$} \\
\hline BA318C17.1 & $20 \mathrm{p} 12.1$ & - & {$[121]$} \\
\hline H19 & $11 \mathrm{p} 15.5$ & $\begin{array}{c}\text { Decrease RB expression, promotes } \\
\text { mesenchymal transition }\end{array}$ & {$[42][122][123]$} \\
\hline PRNCR1 & $8 \mathrm{q} 24$ & CRC related SNP & [119] \\
\hline XIST & $\mathrm{Xq} 13.2$ & - & {$[124][125]$} \\
\hline
\end{tabular}

All these markers were significantly lesser expressed in tumor sample as compared to normal tissue. The most interesting prospect is the use of lncRNA as a therapeutic modality. BC-819 is a treatment targeting H19 and has shown to decrease tumor growth in vivo [96] [97]. A list of lncRNAs found to be important in colorectal cancer is given in the table below (Table 4). Among these lncRNAs, MALAT1 has shown to be useful for targeted therapy against colorectal carcinoma. A study by Qing et al. [98] explored the effects of resveratrol on colorectal cancer. It was found to inhibit invasion and metastasis by down regulating 
MALAT1 which in turn caused decreased Wnt/ $\beta$-catenin signalling. Further studies are required before it can be established as a therapeutic agent.

\section{Conclusion}

The future of lncRNA holds much promise. It could be the key in understanding the pathogenesis of various tumors. It will definitely play a major part in diagnosis and prognostication of various cancers as has been evident in the review above. We have just scratched the surface when coming to the therapeutic utilization of lncRNAs. Several developments are required to further this study of lncRNA like high throughput RNA seq, RNA imaging and a better understanding of the interaction of lncRNA to RNA and DNA. Further in depth studies and analysis is required to truly unlock the potential of lncRNAs.

\section{References}

[1] Bernstein, B.E., Birney, E., Dunham, I., Green, E.D., Gunter, C. and Snyder, M. (2012) An Integrated Encyclopedia of DNA Elements in the Human Genome. Nature, 489, 57-74.

http://www.pubmedcentral.nih.gov/articlerender.fcgi?artid=3439153\&tool=pmcent rez\&rendertype $=$ abstract

[2] Xiao, S., Scott, F., Fierke, C.A. and Engelke, D.R. (2002) Eukaryotic Ribonuclease P: A Plurality of Ribonucleoprotein Enzymes. Annual Review of Biochemistry, 71, 165-189.

https://www.annualreviews.org/doi/abs/10.1146/annurev.biochem.71.110601.135352 https://doi.org/10.1146/annurev.biochem.71.110601.135352

[3] Henras, A.K., Dez, C. and Henry, Y. (2004) RNA Structure and Function in C/D and H/ACA s(no)RNPs. Current Opinion in Structural Biology, 14, 335-343. https://doi.org/10.1016/j.sbi.2004.05.006

[4] Derrien, T., Johnson, R., Bussotti, G., Tanzer, A., Djebali, S., Tilgner, H., et al. (2012) The GENCODE v7 Catalog of Human Long Noncoding RNAs Analysis of Their Gene Structure, Evolution, and Expression. Genome Research, 22, 1755-1789. https://doi.org/10.1101/gr.132159.111

[5] Wang, K.C. and Chang, H.Y. (2011) Molecular Mechanisms of Long Noncoding RNAs. Molecular Cell, 43, 904-914. https://doi.org/10.1016/j.molcel.2011.08.018

[6] Chen, Y., Li, C., Pan, Y., Han, S., Feng, B., Gao, Y., et al. (2016) The Emerging Role and Promise of Long Noncoding RNAs in Lung Cancer Treatment. Cellular Physiology and Biochemistry, 38, 2194-2206. https://doi.org/10.1159/000445575

[7] Mercer, T.R., Dinger, M.E. and Mattick, J.S. (2009) Long Non-Coding RNAs: Insights into Functions. Nature Reviews Genetics, 10, 155-159. https://doi.org/10.1038/nrg2521

[8] Chen, L. (2016) Linking Long Noncoding RNA Localization and Function. Trends in Biochemical Sciences, 41, 761-772. https://doi.org/10.1016/j.tibs.2016.07.003

[9] Cabili, M.N., Dunagin, M.C., McClanahan, P.D., Biaesch, A., Padovan-Merhar, O., Regev, A., et al. (2015) Localization and Abundance Analysis of Human lncRNAs at Single-Cell and Single-Molecule Resolution. Genome Biology, 16, 20. https://doi.org/10.1186/s13059-015-0586-4

[10] Lennox, K.A. and Behlke, M.A. (2016) Cellular Localization of Long Non-Coding 
RNAs Affects Silencing by RNAi More than by Antisense Oligonucleotides. Nucleic Acids Research, 44, 863-877. https://doi.org/10.1093/nar/gkv1206

[11] Fatica, A. and Bozzoni, I. (2014) Long Non-Coding RNAs: New Players in Cell Differentiation and Development. Nature Reviews Genetics, 15, 7-21.

http://www.ncbi.nlm.nih.gov/pubmed/24296535\%5Cn https://doi.org/10.1038/nrg3606

[12] Degirmenci, U. and Lei, S. (2016) Role of lncRNAs in Cellular Aging. Frontiers in Endocrinology, 7, 151. https://doi.org/10.3389/fendo.2016.00151

[13] Mercer, T.R. and Mattick, J.S. (2013) Structure and Function of Long Noncoding RNAs in Epigenetic Regulation. Nature Structural \& Molecular Biology, 20, 300-307. http://www.nature.com/doifinder/10.1038/nsmb.2480 https://doi.org/10.1038/nsmb.2480

[14] Gong, C. and Maquat, L.E. (2011) LncRNAs Transactivate STAU1-Mediated mRNA Decay by Duplexing with 3' UTRs via Alu Elements. Nature, 470, 284-290. https://doi.org/10.1038/nature09701

[15] Cao, J. (2014) The Functional Role of Long Non-Coding RNAs and Epigenetics. Biological Procedures Online, 16, 11. https://doi.org/10.1186/1480-9222-16-11

[16] Kung, J.T.Y., Colognori, D. and Lee, J.T. (2013) Long Noncoding RNAs: Past, Present, and Future. Genetics, 193, 651-669.

http://www.genetics.org/cgi/doi/10.1534/genetics.112.146704 https://doi.org/10.1534/genetics.112.146704

[17] Ulitsky, I. and Bartel, D.P. (2013) lincRNAs: Genomics, Evolution, and Mechanisms. Cell, 154, 26-46. https://doi.org/10.1016/j.cell.2013.06.020

[18] Saayman, S., Ackley, A., Turner, A.M.W., Famiglietti, M., Bosque, A., Clemson, M., et al. (2014) An HIV-Encoded Antisense Long Noncoding RNA Epigenetically Regulates Viral Transcription. Molecular Therapy, 22, 1164-1175. https://doi.org/10.1038/mt.2014.29

[19] Iyer, M.K., Niknafs, Y.S., Malik, R., Singhal, U., Sahu, A., Hosono, Y., et al. (2015) The Landscape of Long Noncoding RNAs in the Human Transcriptome. Nature Genetics, 47, 199-208. https://doi.org/10.1038/ng.3192

[20] Sun, L., Mathews, L.A., Cabarcas, S.M., Zhang, X., Yang, A., Zhang, Y., et al. (2013) Epigenetic Regulation of SOX9 by the NF- $\kappa B$ Signaling Pathway in Pancreatic Cancer Stem Cells. Stem Cells, 31, 1454-1466.

http://www.pubmedcentral.nih.gov/articlerender.fcgi?artid=3775871\&tool=pmcent rez\&rendertype $=$ abstract https://doi.org/10.1002/stem.1394

[21] Ni, X.G., Bai, X.F., Mao, Y.L., Shao, Y.F., Wu, J.X., Shan, Y., et al. (2005) The Clinical Value of Serum CEA, CA19-9, and CA242 in the Diagnosis and Prognosis of Pancreatic Cancer. European Journal of Surgical Oncology, 31, 164-169. https://doi.org/10.1016/j.ejso.2004.09.007

[22] Wang, Y., Li, Z., Zheng, S., Zhou, Y., Zhao, L., Ye, H., et al. (2015) Expression Profile of Long Non-Coding RNAs in Pancreatic Cancer and Their Clinical Significance as Biomarkers. Oncotarget, 6, 35684-35698.

https://www.ncbi.nlm.nih.gov/pubmed/26447755 https://doi.org/10.18632/oncotarget.5533

[23] Xie, Z., Chen, X., Li, J., Guo, Y., Li, H., Pan, X., et al. (2016) Salivary HOTAIR and PVT1 as Novel Biomarkers for Early Pancreatic Cancer. Oncotarget, 7, 25408-25419. https://doi.org/10.18632/oncotarget.8323

[24] Kim, K., Jutooru, I., Chadalapaka, G., Johnson, G., Frank, J., Burghardt, R., et al. 
(2013) HOTAIR Is a Negative Prognostic Factor and Exhibits Pro-Oncogenic Activity in Pancreatic Cancer. Oncogene, 32, 1616-1625.

https://doi.org/10.1038/onc.2012.193

[25] Li, J., Liu, D., Hua, R., Zhang, J., Liu, W., Huo, Y., et al. (2014) Long Non-Coding RNAs Expressed in Pancreatic Ductal Adenocarcinoma and lncRNA BC008363 an Independent Prognostic Factor in PDAC. Pancreatology, 14, 385-390. https://doi.org/10.1016/j.pan.2014.07.013

[26] Liu, J.-H., Chen, G., Dang, Y.-W., Li, C.-J. and Luo, D.-Z. (2014) Expression and Prognostic Significance of lncRNA MALAT1 in Pancreatic Cancer Tissues. Asian Pacific Journal of Cancer Prevention, 15, 2971-2977.

http://www.ncbi.nlm.nih.gov/pubmed/24815433 https://doi.org/10.7314/APJCP.2014.15.7.2971

[27] Li, Z., Zhao, X., Zhou, Y., Liu, Y., Zhou, Q., Ye, H., et al. (2015) The Long Non-Coding RNA HOTTIP Promotes Progression and Gemcitabine Resistance by Regulating HOXA13 in Pancreatic Cancer. Journal of Translational Medicine, 13, 84. https://doi.org/10.1186/s12967-015-0442-Z

[28] You, L., Chang, D., Du, H.Z. and Zhao, Y.P. (2011) Genome-Wide Screen Identifies PVT1 as a Regulator of Gemcitabine Sensitivity in Human Pancreatic Cancer Cells. Biochemical and Biophysical Research Communications, 407, 1-6. https://doi.org/10.1016/j.bbrc.2011.02.027

[29] Jiao, F., Hu, H., Han, T., Yuan, C., Wang, L., Jin, Z., et al. (2015) Long Noncoding RNA MALAT-1 Enhances Stem Cell-Like Phenotypes in Pancreatic Cancer Cells. International Journal of Molecular Sciences, 16, 6677-6693. https://doi.org/10.3390/ijms16046677

[30] Hanna, N., Ohana, P., Konikoff, F.M., Leichtmann, G., Hubert, A., Appelbaum, L., et al. (2012) Phase 1/2a, Dose-Escalation, Safety, Pharmacokinetic and Preliminary Efficacy Study of Intratumoral Administration of BC-819 in Patients with Unresectable Pancreatic Cancer. Cancer Gene Therapy, 19, 374-381. https://doi.org/10.1038/cgt.2012.10

[31] Rinn, J.L., Kertesz, M., Wang, J.K., Squazzo, S.L., Xu, X., Brugmann, S.A., et al. (2007) Functional Demarcation of Active and Silent Chromatin Domains in Human HOX Loci by Noncoding RNAs. Cell, 129, 1311-1323. https://doi.org/10.1016/j.cell.2007.05.022

[32] Chiyomaru, T., Fukuhara, S., Saini, S., Majid, S., Deng, G., Shahryari, V., et al. (2014) Long Non-Coding RNA HOTAIR Is Targeted and Regulated by miR-141 in Human Cancer Cells. Journal of Biological Chemistry, 289, 12550-12565. https://doi.org/10.1074/jbc.M113.488593

[33] Zhang, K., Sun, X., Zhou, X., Han, L., Chen, L., Shi, Z., et al. (2015) Long Non-Coding RNA HOTAIR Promotes Glioblastoma Cell Cycle Progression in An EZH2 Dependent Manner. Oncotarget, 6, 537-546.

http://www.ncbi.nlm.nih.gov/pubmed/25428914

https://doi.org/10.18632/oncotarget.2681

[34] Kogo, R., Shimamura, T., Mimori, K., Kawahara, K., Imoto, S., Sudo, T., et al. (2011) Long Noncoding RNA HOTAIR Regulates Polycomb-Dependent Chromatin Modification and Is Associated with Poor Prognosis in Colorectal Cancers. Cancer Research, 71, 6320-6326. http://www.ncbi.nlm.nih.gov/pubmed/21862635 https://doi.org/10.1158/0008-5472.CAN-11-1021

[35] Quagliata, L., Matter, M.S., Piscuoglio, S., Arabi, L., Ruiz, C., Procino, A., et al. (2014) Long Noncoding RNA HOTTIP/HOXA13 Expression Is Associated with 
Disease Progression and Predicts Outcome in Hepatocellular Carcinoma Patients. Hepatology, 59, 911-923. https://doi.org/10.1002/hep.26740

[36] Wang, K.C., Yang, Y.W., Liu, B., Sanyal, A., Corces-Zimmerman, R., Chen, Y., et al. (2011) A Long Noncoding RNA Maintains Active Chromatin to Coordinate Homeotic Gene Expression. Nature, 472, 120-124.

http://www.ncbi.nlm.nih.gov/entrez/query.fcgi?cmd=Retrieve\&db=PubMed\&dopt= Citation\&list_uids $=21423168$ https://doi.org/10.1038/nature09819

[37] Ji, P., Diederichs, S., Wang, W., Böing, S., Metzger, R., Schneider, P.M., et al. (2003) MALAT-1, a Novel Noncoding RNA, and Thymosin $\beta 4$ Predict Metastasis and Survival in Early-Stage Non-Small Cell Lung Cancer. Oncogene, 22, 8031-8041. https://doi.org/10.1038/sj.onc.1206928

[38] Li, H., Yu, B., Li, J., Su, L., Yan, M., Zhu, Z., et al. (2014) Overexpression of lncRNA H19 Enhances Carcinogenesis and Metastasis of Gastric Cancer. Oncotarget, 5, 2318-2329. http://www.oncotarget.com/fulltext/1913 https://doi.org/10.18632/oncotarget.1913

[39] Sun, Y.W., Chen, Y.F., Li, J., Huo, Y.M., Liu, D.J., Hua, R., et al. (2014) A Novel Long Non-Coding RNA ENST00000480739 Suppresses Tumour Cell Invasion by Regulating OS-9 and HIF-1alpha in Pancreatic Ductal Adenocarcinoma. British Journal of Cancer, 111, 2131-2141.

http://www.ncbi.nlm.nih.gov/pubmed/25314054 https://doi.org/10.1038/bjc.2014.520

[40] Müller, S., Raulefs, S., Bruns, P., Afonso-Grunz, F., Plötner, A., Thermann, R., et al. (2015) Next-Generation Sequencing Reveals Novel Differentially Regulated mRNAs, lncRNAs, miRNAs, sdRNAs and A piRNA in Pancreatic Cancer. Molecular Cancer, 14, 94.

[41] Ye, Y., Chen, J., Zhou, Y., Fu, Z., Zhou, Q., Wang, Y.X., et al. (2015) High Expression of $A F A P 1-A S 1$ Is Associated with Poor Survival and Short-Term Recurrence in pancreatic Ductal Adenocarcinoma. Journal of Translational Medicine, 13, 137. https://doi.org/10.1186/s12967-015-0490-4

[42] Yoshimizu, T., Miroglio, A., Ripoche, M.-A., Gabory, A., Vernucci, M., Riccio, A., et al. (2008) The H19 Locus Acts in Vivo as a Tumor Suppressor. Proceedings of the National Academy of Sciences, 105, 12417-12422.

http://www.pubmedcentral.nih.gov/articlerender.fcgi?artid=2527926\&tool=pmcent rez\&rendertype $=$ abstract https://doi.org/10.1073/pnas.0801540105

[43] Arney, K.L. (2003) H19 and Igf2-Enhancing the Confusion? Trends in Genetics, 19, 17-23.

[44] Matouk, I.J., Raveh, E., Abu-lail, R., Mezan, S., Gilon, M., Gershtain, E., et al. (2014) Oncofetal H19 RNA Promotes Tumor Metastasis. Biochimica et Biophysica Acta-Molecular Cell Research, 1843, 1414-1426. https://doi.org/10.1016/j.bbamcr.2014.03.023

[45] Zhang, L., Yang, F., Yuan, J.H., Yuan, S.X., Zhou, W.P., Huo, X.S., et al. (2013) Epigenetic Activation of the MiR-200 Family Contributes to H19-Mediated Metastasis Suppression in Hepatocellular Carcinoma. Carcinogenesis, 34, 577-586. https://doi.org/10.1093/carcin/bgs381

[46] Ma, C., Nong, K., Zhu, H., Wang, W., Huang, X., Yuan, Z., et al. (2014) H19 Promotes Pancreatic Cancer Metastasis by Derepressing let-7's Suppression on Its Target HMGA2-Mediated EMT. Tumor Biology, 35, 9163-9169. 
https://doi.org/10.1007/s13277-014-2185-5

[47] Kong, R., Zhang, E.B., Yin, D.D., You, L.H., Xu, T.P., Chen, W.M., et al. (2015) Long Noncoding RNA PVT1 Indicates a Poor Prognosis of Gastric Cancer and Promotes Cell Proliferation through Epigenetically Regulating p15 and p16. Molecular Cancer, 14, 82. https://doi.org/10.1186/s12943-015-0355-8

[48] Peng, W., Gao, W., Feng, J. (2014) Long Noncoding RNA HULC Is a Novel Biomarker of Poor Prognosis in Patients with Pancreatic Cancer. Medical Oncology, 31, 346.

[49] Lu, X., Fang, Y., Wang, Z., Xie, J., Zhan, Q., Deng, X., et al. (2013) Downregulation of gas5 Increases Pancreatic Cancer Cell Proliferation by Regulating CDK6. Cell and Tissue Research, 354, 891-896. https://doi.org/10.1007/s00441-013-1711-x

[50] Hu, P., Shangguan, J. and Zhang, L. (2015) Downregulation of NUF2 Inhibits Tumor Growth and Induces Apoptosis by Regulating lncRNA AF339813. International Journal of Clinical and Experimental Pathology, 8, 2638-2648.

[51] Siegel, R.L., Miller, K.D. and Jemal, A. (2016) Cancer Statistics, 2016. CA: A Cancer Journal for Clinicians, 66, 7-30. https://doi.org/10.3322/caac.21332

[52] Hamashima, C., Shabana, M., Okada, K., Okamoto, M. and Osaki, Y. (2015) Mortality Reduction from Gastric Cancer by Endoscopic and Radiographic Screening. Cancer Science, 106, 1744-1749. https://doi.org/10.1111/cas.12829

[53] Huang, Y.-K. and Yu, J.-C. (2015) Circulating microRNAs and Long Non-Coding RNAs in Gastric Cancer Diagnosis: An Update and Review. World Journal of Gastroenterology, 21, 9863-9886. https://doi.org/10.3748/wjg.v21.i34.9863

[54] Sun, M., Nie, F., Wang, Y., Zhang, Z., Hou, J., He, D., et al. (2016) LncRNA HOXA11-AS Promotes Proliferation and Invasion of Gastric Cancer by Scaffolding the Chromatin Modification Factors PRC2, LSD1, and DNMT1. Cancer Research, 76, 6299-6310. https://doi.org/10.1158/0008-5472.CAN-16-0356

[55] Xu, T., Huang, M., Xia, R., Liu, X., Sun, M., Yin, L., et al. (2014) Decreased Expression of the Long Non-Coding RNA FENDRR Is Associated with Poor Prognosis in Gastric Cancer and FENDRR Regulates Gastric Cancer Cell Metastasis by Affecting Fibronectin1 Expression. Journal of Hematology \& Oncology, 7, 63.

http://jhoonline.biomedcentral.com/articles/10.1186/s13045-014-0063-7 https://doi.org/10.1186/s13045-014-0063-7

[56] Du, M., Wang, W., Jin, H., Wang, Q., Ge, Y., Lu, J., et al. (2015) The Association Analysis of lncRNA HOTAIR Genetic Variants and Gastric Cancer Risk in a Chinese Population. Oncotarget, 6, 31255-31262.

[57] Huang, M., Hou, J., Wang, Y., Xie, M., Wei, C., Nie, F., et al. (2017) Long Noncoding RNA LINC00673 Is Activated by SP1 and Exerts Oncogenic Properties by Interacting with LSD1 and EZH2 in Gastric Cancer. Molecular Therapy, 25, 1014-1026. https://doi.org/10.1016/j.ymthe.2017.01.017

[58] Zhao, L., Han, T., Li, Y., Sun, J., Zhang, S., Liu, Y., et al. (2017) The lncRNA SNHG5/miR-32 Axis Regulates Gastric Cancer Cell Proliferation \& Migration by Targeting KLF4. The FASEB Journal, 31, 893-903. https://doi.org/10.1096/fj.201600994R

[59] Liu, Y.W., Xia, R., Lu, K., Xie, M., Yang, F., Sun, M., et al. (2017) LincRNAFEZF1-AS1 Represses p21 Expression to Promote Gastric Cancer Proliferation through LSD1-Mediated H3K4me2 Demethylation. Molecular Cancer, 16, 39.

[60] Xu, M.-D., Wang, Y., Weng, W., Wei, P., Qi, P., Zhang, Q., et al. (2017) A Positive Feedback Loop of lncRNA-PVT1 and FOXM1 Facilitates Gastric Cancer Growth 
and Invasion. Clinical Cancer Research, 23, 2071-2080. https://doi.org/10.1158/1078-0432.CCR-16-0742

[61] Yang, F., Xue, X., Zheng, L., Bi, J., Zhou, Y., Zhi, K., et al. (2014) Long Non-Coding RNA GHET1 Promotes Gastric Carcinoma Cell Proliferation by Increasing c-Myc mRNA Stability. The FEBS Journal, 281, 802-813. https://doi.org/10.1111/febs.12625

[62] Xu, T.P., Liu, X.X., Xia, R., Yin, L., Kong, R., Chen, W.M., et al. (2015) SP1-Induced Upregulation of the long Noncoding RNA TINCR Regulates Cell Proliferation and Apoptosis by Affecting KLF2 mRNA Stability in Gastric Cancer. Oncogene, 34, 5648-5661. https://doi.org/10.1038/onc.2015.18

[63] Zhang, E., Kong, R., Yin, D., You, L., Sun, M., Han, L., et al. (2014) Long Noncoding RNA ANRIL Indicates a Poor Prognosis of Gastric Cancer and Promotes Tumor Growth by Epigenetically Silencing of miR-99a/miR-449a. Oncotarget, 5, 2276-2292. https://doi.org/10.18632/oncotarget.1902

[64] Liu, Y.W., Sun, M., Xia, R., Zhang, E.B., Liu, X.H., Zhang, Z.H., et al. (2015) LincHOTAIR Epigenetically Silences miR34a by Binding to PRC2 to Promote the Epithelial-to-Mesenchymal Transition in Human Gastric Cancer. Cell Death \& Disease, 6, e1802.

[65] Hu, Y., Wang, J., Qian, J., Kong, X., Tang, J., Wang, Y., et al. (2014) Long Noncoding RNA GAPLINC Regulates CD44-Dependent Cell Invasiveness and Associates with Poor Prognosis of Gastric Cancer. Cancer Research, 74, 6890-6902. https://doi.org/10.1158/0008-5472.CAN-14-0686

[66] Xia, T., Chen, S., Jiang, Z., Shao, Y., Jiang, X., Li, P., et al. (2015) Long Noncoding RNA FER1L4 Suppresses Cancer Cell Growth by Acting as a Competing Endogenous RNA and Regulating PTEN Expression. Scientific Reports, 5, Article No. 13445.

[67] Liu, Z., Shao, Y., Tan, L., Shi, H., Chen, S. and Guo, J. (2014) Clinical Significance of the Low Expression of FER1L4 in Gastric Cancer Patients. Tumor Biology, 35, 9613-9617. http://www.ncbi.nlm.nih.gov/pubmed/24961353 https://doi.org/10.1007/s13277-014-2259-4

[68] Liu, Y., Zhao, J., Zhang, W., Gan, J., Hu, C., Huang, G., et al. (2015) IncRNA GAS Enhances G1 Cell Cycle Arrest via Binding to YBX1 to Regulate p21 Expression in Stomach Cancer. Scientific Reports, 5, Article No. 10159.

[69] Lee, K.-S., Park, J.-L., Lee, K., Richardson, L.E., Johnson, B.H., Lee, H.-S., et al. (2014) nc886, a Non-Coding RNA of Anti-Proliferative Role, Is Suppressed by CpG DNA Methylation in Human Gastric Cancer. Oncotarget, 5, 3944-3955.

http://www.impactjournals.com/oncotarget/index.php?journal=oncotarget\&page=a rticle\&op=view\&path\%5B\%5D=2047\&path\%5B\%5D=3069 https://doi.org/10.18632/oncotarget.2047

[70] Sun, T.T., He, J., Liang, Q., Ren, L.L., Yan, T.T., Yu, T.C., et al. (2016) LncRNA GClnc1 Promotes Gastric Carcinogenesis and May Act as a Modular Scaffold of WDR5 and KAT2A Complexes to Specify the Histone Modification Pattern. Cancer Discovery, 6, 784-801. https://doi.org/10.1158/2159-8290.CD-15-0921

[71] Lü, M.H., Tang, B., Zeng, S., Hu, C.J., Xie, R., Wu, Y.Y., et al. (2016) Long Noncoding RNA BC032469, a Novel Competing Endogenous RNA, Upregulates hTERT Expression by Sponging MIR-1207-5p and Promotes Proliferation in Gastric Cancer. Oncogene, 35, 3524-3534. https://doi.org/10.1038/onc.2015.413

[72] Petrick, J.L., Braunlin, M., Laversanne, M., Valery, P.C., Bray, F. and McGlynn, K.A. (2016) International Trends in Liver Cancer Incidence, Overall and by Histologic Subtype, 1978-2007. International Journal of Cancer, 139, 1534-1545. 
https://doi.org/10.1002/ijc.30211

[73] Nishida, N. and Kudo, M. (2016) Clinical Significance of Epigenetic Alterations in Human Hepatocellular Carcinoma and Its Association with Genetic Mutations. Digestive Diseases, 34, 708-713. https://doi.org/10.1159/000448863

[74] Matouk, I.J., DeGroot, N., Mezan, S., Ayesh, S., Abu-Lail, R., Hochberg, A., et al. (2007) The H19 Non-Coding RNA Is Essential for Human Tumor Growth. PLoS ONE, 2, e845. https://doi.org/10.1371/journal.pone.0000845

[75] Hernandez, J.M., Elahi, A., Clark, C.W., Wang, J., Humphries, L.A., Centeno, B., et al. (2013) miR-675 Mediates Downregulation of Twist1 and Rb in AFP-Secreting Hepatocellular Carcinoma. Annals of Surgical Oncology, 20, 625-635. https://doi.org/10.1245/s10434-013-3106-3

[76] Yang, Z., Zhou, L., Wu, L.-M., Lai, M.-C., Xie, H.-Y., Zhang, F., et al. (2011) Overexpression of Long Non-Coding RNA HOTAIR Predicts Tumor Recurrence in Hepatocellular Carcinoma Patients Following Liver Transplantation. Annals of Surgical Oncology, 18, 1243-1250.

http://www.springerlink.com/index/10.1245/s10434-011-1581-y https://doi.org/10.1245/s10434-011-1581-y

[77] Geng, Y.J., Xie, S.L., Li, Q., Ma, J. and Wang, G.Y. (2011) Large Intervening Non-Coding RNA HOTAIR Is Associated with Hepatocellular Carcinoma Progression. Journal of International Medical Research, 39, 2119-2128. https://doi.org/10.1177/147323001103900608

[78] Xie, H., Ma, H. and Zhou, D. (2013) Plasma HULC as a Promising Novel Biomarker for the Detection of Hepatocellular Carcinoma. BioMed Research International, 2013, Article ID: 136106.

[79] Wang, X., Zhang, W., Tang, J., Huang, R., Li, J., Xu, D., et al. (2016) LINC01225 Promotes Occurrence and Metastasis of Hepatocellular Carcinoma in an Epidermal Growth Factor Receptor-Dependent Pathway. Cell Death \& Disease, 7, e2130. https://doi.org/10.1038/cddis.2016.26

[80] Lv, J., Ma, L., Chen, X.L., Huang, X.H. and Wang, Q. (2014) Downregulation of LncRNAH19 and MiR-675 Promotes Migration and Invasion of Human Hepatocellular Carcinoma Cells through AKT/GSK-3 $\beta /$ Cdc25A Signaling Pathway. Journal of Huazhong University of Science and Technology [Medical Sciences], 34, 363-369. https://doi.org/10.1007/s11596-014-1284-2

[81] Zhang, Y., Li, Z., Zhang, Y., Zhong, Q., Chen, Q. and Zhang, L. (2015) Molecular Mechanism of HEIH and HULC in the Proliferation and Invasion of Hepatoma Cells. International Journal of Clinical and Experimental Medicine, 8, 12956-12962.

[82] Lai, M.C., Yang, Z., Zhou, L., Zhu, Q.Q., Xie, H.Y., Zhang, F., et al. (2012) Long Non-Coding RNA MALAT-1 Overexpression Predicts Tumor Recurrence of Hepatocellular Carcinoma after Liver Transplantation. Medical Oncology, 29, 1810-1816. http://www.ncbi.nlm.nih.gov/pubmed/21678027 https://doi.org/10.1007/s12032-011-0004-Z

[83] Shi, Y., Song, Q., Yu, S., Hu, D. and Zhuang, X. (2015) Microvascular Invasion in Hepatocellular Carcinoma Overexpression Promotes Cell Proliferation and Inhibits Cell Apoptosis of Hepatocellular Carcinoma via Inhibiting miR-199a Expression. OncoTargets and Therapy, 8, 2303-2310. https://doi.org/10.2147/OTT.S86807

[84] Zhu, J., Liu, S., Ye, F., Shen, Y., Tie, Y., Zhu, J., et al. (2015) Long Noncoding RNA MEG3 Interacts with p53 Protein and Regulates Partial p53 Target Genes in hepatoma Cells. PLoS ONE, 10, e0139790. https://doi.org/10.1371/journal.pone.0139790

[85] Liu, Z., Dou, C., Yao, B., Xu, M., Ding, L., Wang, Y., et al. (2016) Ftx Non Coding 
RNA-Derived miR-545 Promotes Cell Proliferation by Targeting RIG-I in Hepatocellular Carcinoma. Oncotarget, 7, 25350-25365.

http://www.impactjournals.com/oncotarget/index.php?journal=oncotarget\&page=a rticle\&op=view\&path\%5B\%5D=8129\&path\%5B\%5D=23948

[86] Liu, F., Yuan, J.H., Huang, J.F., Yang, F., Wang, T.T., Ma, J.Z., et al. (2016) Long Noncoding RNA FTX Inhibits Hepatocellular Carcinoma Proliferation and Metastasis by Binding MCM2 and miR-374a. Oncogene, 35, 5422-5434.

https://doi.org/10.1038/onc.2016.80

[87] Arends, J.W. (2000) Molecular Interactions in the Vogelstein Model of Colorectal Carcinoma. Journal of Pathology, 190, 412-416.

https://doi.org/10.1002/(SICI)1096-9896(200003)190:4<412::AID-PATH533>3.0.C $\underline{\mathrm{O} ; 2-\mathrm{P}}$

[88] Hibi, K., Nakamura, H., Hirai, A., Fujikake, Y., Kasai, Y., Akiyama, S., et al. (1996) Loss of H19 Imprinting in Esophageal Cancer. Cancer Research, 56, 480-482.

[89] Xu, M.-D., Qi, P. and Du, X. (2014) Long Non-Coding RNAs in Colorectal Cancer: Implications for Pathogenesis and Clinical Application. Modern Pathology, 27, 1310-1320. http://www.ncbi.nlm.nih.gov/pubmed/24603586 https://doi.org/10.1038/modpathol.2014.33

[90] Ling, H., Spizzo, R., Atlasi, Y., Nicoloso, M., Shimizu, M., Redis, R.S., et al. (2013) CCAT2, a Novel Noncoding RNA Mapping to 8q24, Underlies Metastatic Progression and Chromosomal Instability in Colon Cancer. Genome Research, 23, 1446-1461. https://doi.org/10.1101/gr.152942.112

[91] Tanaka, K., Shiota, G., Meguro, M., Mitsuya, K., Oshimura, M. and Kawasaki, H. (2001) Loss of Imprinting of Long QT Intronic Transcript 1 in Colorectal Cancer. Oncology, 60, 268-273. https://doi.org/10.1159/000055328

[92] Pedersen, S.K., Mitchell, S.M., Graham, L.D., McEvoy, A., Thomas, M.L., Baker, R.T., et al. (2014) CAHM, a Long Non-Coding RNA Gene Hypermethylated in Colorectal Neoplasia. Epigenetics, 9, 1071-1082. https://doi.org/10.4161/epi.29046

[93] Zhai, H., Fesler, A., Schee, K., Fodstad, O., Flatmark, K. and Ju, J. (2013) Clinical Significance of Long Intergenic Noncoding RNA-p21 in Colorectal Cancer. Clinical Colorectal Cancer, 12, 261-266. https://doi.org/10.1016/j.clcc.2013.06.003

[94] Qi, P., Xu, M.-D., Ni, S.-J., Shen, X.-H., Wei, P., Huang, D., et al. (2015) Down-Regulation of ncRAN, a Long Non-Coding RNA, Contributes to Colorectal Cancer Cell Migration and Invasion and Predicts Poor Overall Survival for Colorectal Cancer Patients. Molecular Carcinogenesis, 54, 742-750. http://www.ncbi.nlm.nih.gov/pubmed/24519959

[95] Qi, P., Xu, M., Ni, S., Huang, D., Wei, P., Tan, C., et al. (2013) Low Expression of LOC285194 Is Associated with Poor Prognosis in Colorectal Cancer. Journal of Translational Medicine, 11, 122.

http://translational-medicine.biomedcentral.com/articles/10.1186/1479-5876-11-122 https://doi.org/10.1186/1479-5876-11-122

[96] Smaldone, M.C. and Davies, B.J. (2010) BC-819, a Plasmid Comprising the H19 Gene Regulatory Sequences and Diphtheria Toxin A, for the Potential Targeted Therapy of Cancers. Current Opinion in Molecular Therapeutics, 12, 607-616. http://www.ncbi.nlm.nih.gov/pubmed/20886393

[97] Sorin, V., Ohana, P., Mizrahi, A., Matouk, I., Birma, T., Hochberg, A., et al. (2011) Regional Therapy with DTA-H19 Vector Suppresses Growth of Colon Adenocarcinoma Metastases in the Rat Liver. International Journal of Oncology, 39, 1407-1412.

[98] Ji, Q., Liu, X., Fu, X., Zhang, L., Sui, H., Zhou, L., et al. (2013) Resveratrol Inhibits 
Invasion and Metastasis of Colorectal Cancer Cells via MALAT1 Mediated Wnt/ $\beta$-Catenin Signal Pathway. PLoS ONE, 8, e78700.

https://doi.org/10.1371/journal.pone.0078700

[99] Ma, Y., Yang, Y., Wang, F., Moyer, M.P., Wei, Q., Zhang, P., et al. (2016) Long Non-Coding RNA CCAL Regulates Colorectal Cancer Progression by Activating Wnt/ $\beta$-Catenin Signalling Pathway via Suppression of Activator Protein 2a. Gut, 65, 1494-1504. https://doi.org/10.1136/gutjnl-2014-308392

[100] Kam, Y., Rubinstein, A., Naik, S., Djavsarov, I., Halle, D., Ariel, I., et al. (2014) Detection of a Long Non-Coding RNA (CCAT1) in Living Cells and Human Adenocarcinoma of Colon Tissues Using FIT-PNA Molecular Beacons. Cancer Letters, 352, 90-96. https://doi.org/10.1016/j.canlet.2013.02.014

[101] Nissan, A., Stojadinovic, A., Mitrani-Rosenbaum, S., Halle, D., Grinbaum, R., Roistacher, M., et al. (2012) Colon Cancer Associated Transcript-1: A Novel RNA Expressed in Malignant and Pre-Malignant Human Tissues. International Journal of Cancer, 130, 1598-1606. https://doi.org/10.1002/ijc.26170

[102] Alaiyan, B., Ilyayev, N., Stojadinovic, A., Izadjoo, M., Roistacher, M., Pavlov, V., et al. (2013) Differential Expression of Colon Cancer Associated Transcript1 (CCAT1) along the Colonic Adenoma-Carcinoma Sequence. BMC Cancer, 13, 196.

[103] Xiang, J.F., Yin, Q.F., Chen, T., Zhang, Y., Zhang, X.O., Wu, Z., et al. (2014) Human Colorectal Cancer-Specific CCAT1-L lncRNA Regulates Long-Range Chromatin Interactions at the MYCLocus. Cell Research, 24, 513-531. https://doi.org/10.1038/cr.2014.35

[104] Graham, L.D., Pedersen, S.K., Brown, G.S., Ho, T., Kassir, Z., Moynihan, A.T., et al. (2011) Colorectal Neoplasia Differentially Expressed (CRNDE), a Novel Gene with Elevated Expression in Colorectal Adenomas and Adenocarcinomas. Genes and Cancer, 2, 829-840. https://doi.org/10.1177/1947601911431081

[105] Ellis, B.C., Graham, L.D. and Molloy, P.L. (2014) CRNDE, a Long Non-Coding RNA Responsive to Insulin/IGF Signaling, Regulates Genes Involved in Central Metabolism. Biochimica et Biophysica Acta (BBA)-Molecular Cell Research, 1843, 372-386. https://doi.org/10.1016/j.bbamcr.2013.10.016

[106] Yochum, G.S., Cleland, R., McWeeney, S. and Goodman, R.H. (2007) An Antisense Transcript Induced by Wnt/ $\beta$-Catenin Signaling Decreases E2F4. Journal of Biological Chemistry, 282, 871-878. https://doi.org/10.1074/jbc.M609391200

[107] Matouk, I.J., Abbasi, I., Hochberg, A., Galun, E., Dweik, H. and Akkawi, M. (2009) Highly Upregulated in Liver Cancer Noncoding RNA Is Overexpressed in Hepatic Colorectal Metastasis. European Journal of Gastroenterology \& Hepatology, 21, 688-692. https://doi.org/10.1097/MEG.0b013e328306a3a2

[108] Nakano, S., Murakami, K., Meguro, M., Soejima, H., Higashimoto, K., Urano, T., et al. (2006) Expression Profile of LIT1/KCNQ1OT1 and Epigenetic Status at the KvDMR1 in Colorectal Cancers. Cancer Science, 97, 1147-1154. https://doi.org/10.1111/j.1349-7006.2006.00305.x

[109] Yuan, J.H., Yang, F., Wang, F., Ma, J.Z., Guo, Y.J., Tao, Q.F., et al. (2014) A Long Noncoding RNA Activated by TGF- $\beta$ Promotes the Invasion-Metastasis Cascade in Hepatocellular Carcinoma. Cancer Cell, 25, 666-681.

https://doi.org/10.1016/j.ccr.2014.03.010

[110] Franklin, J.L., Rankin, C.R., Levy, S., Snoddy, J.R., Zhang, B., Washington, M.K., et al. (2013) Malignant Transformation of Colonic Epithelial Cells by a Colon-Derived Long Noncoding RNA. Biochemical and Biophysical Research Communications, 440, 99-104. https://doi.org/10.1016/j.bbrc.2013.09.040 
[111] Ge, X., Chen, Y., Liao, X., Liu, D., Li, F., Ruan, H., et al. (2013) Overexpression of Long Noncoding RNA PCAT-1 Is a Novel Biomarker of Poor Prognosis in Patients with Colorectal Cancer. Medical Oncology, 30, 558. https://doi.org/10.1007/s12032-013-0588-6

[112] Takahashi, Y., Sawada, G., Kurashige, J., Uchi, R., Matsumura, T., Ueo, H., et al. (2014) Amplification of PVT-1 Is Involved in Poor Prognosis via Apoptosis Inhibition in Colorectal Cancers. British Journal of Cancer, 110, 164-171. https://doi.org/10.1038/bjc.2013.698

[113] Calin, G.A., Liu, C.G., Ferracin, M., Hyslop, T., Spizzo, R., Sevignani, C., et al. (2007) Ultraconserved Regions Encoding ncRNAs Are Altered in Human Leukemias and Carcinomas. Cancer Cell, 12, 215-229. https://doi.org/10.1016/j.ccr.2007.07.027

[114] Tsang, W.P., Wong, T.W.L., Cheung, A.H.H., Co, C.N.N. and Kwok, T.T. (2007) Induction of Drug Resistance and Transformation in Human Cancer Cells by the Noncoding RNA CUDR. RNA, 13, 890-898.

http://www.readcube.com/articles/10.1261/rna.359007 https://doi.org/10.1261/rna.359007

[115] Shi, Y., Liu, Y., Wang, J., Jie, D., Yun, T., Li, W., et al. (2015) Downregulated Long Noncoding RNA BANCR Promotes the Proliferation of Colorectal Cancer Cells via Downregualtion of p21 Expression. PLOS ONE, 10, e0122679.

[116] Yang, F., Huo, X.S., Yuan, S.X., Zhang, L., Zhou, W.P., Wang, F., et al. (2013) Repression of the Long Noncoding RNA-LET by Histone Deacetylase 3 Contributes to Hypoxia-Mediated Metastasis. Molecular Cell, 49, 1083-1096. https://doi.org/10.1016/j.molcel.2013.01.010

[117] Liu, Q., Huang, J., Zhou, N., Zhang, Z., Zhang, A., Lu, Z., et al. (2013) LncRNA loc285194 Is a p53-Regulated Tumor Suppressor. Nucleic Acids Research, 41, 4976-4987. https://doi.org/10.1093/nar/gkt182

[118] Zhou, Y., Zhong, Y., Wang, Y., Zhang, X., Batista, D.L. Gejman, R., et al. (2007) Activation of p53 by MEG3 Non-Coding RNA. Journal of Biological Chemistry, 282, 24731-24742. https://doi.org/10.1074/jbc.M702029200

[119] Menigatti, M., Staiano, T., Manser, C.N., Bauerfeind, P., Komljenovic, A., Robinson, M., et al. (2013) Epigenetic Silencing of Monoallelically Methylated miRNA Loci in Precancerous Colorectal Lesions. Oncogenesis, 2, e56.

https://doi.org/10.1038/oncsis.2013.21

[120] Poliseno, L., Salmena, L., Zhang, J., Carver, B., Haveman, W.J. and Pandolfi, P.P. (2010) A Coding-Independent Function of Gene and Pseudogene mRNAs Regulates Tumour Biology. Nature, 465, 1033-1038. https://doi.org/10.1038/nature09144

[121] Davison, E.J., Tarpey, P.S., Fiegler, H., Tomlinson, I.P. and Carter, N.P. (2005) Deletion at Chromosome Band 20p12.1 in Colorectal Cancer Revealed by High Resolution Array Comparative Genomic Hybridization. Genes Chromosomes Cancer, 44, 384-391.

http://www.ncbi.nlm.nih.gov/entrez/query.fcgi? cmd=Retrieve\&db=PubMed\&dopt= Citation\&list_uids $=16110499$

[122] Tsang, W.P., Ng, E.K.O., Ng, S.S.M., Jin, H., Yu, J., Sung, J.J.Y., et al. (2010) Oncofetal H19-Derived miR-675 Regulates Tumor Suppressor RB in Human Colorectal Cancer. Carcinogenesis, 31, 350-358. https://doi.org/10.1093/carcin/bgp181

[123] Liang, W., Fu, W., Wong, C., Wang, Y., Wang, W.-M., Hu, G.-X., et al. (2015) The lncRNA H19 Promotes Epithelial to Mesenchymal Transition by Functioning as miRNA Sponges in Colorectal Cancer. Oncotarget, 6, 22513-22525. 
https://doi.org/10.18632/oncotarget.4154

[124] Lassmann, S., Weis, R., Makowiec, F., Roth, J., Danciu, M., Hopt, U., et al. (2007) Array CGH Identifies Distinct DNA Copy Number Profiles of Oncogenes and tumor Suppressor Genes in Chromosomal- and Microsatellite-Unstable Sporadic Colorectal Carcinomas. Journal of Molecular Medicine, 85, 293-304.

http://www.ncbi.nlm.nih.gov/entrez/query.fcgi?cmd=Retrieve\&db=PubMed\&dopt= Citation\&list_uids=17143621

https://doi.org/10.1007/s00109-006-0126-5

[125] Brim, H., Lee, E., Abu-Asab, M.S., Chaouchi, M., Razjouyan, H., Namin, H., et al. (2012) Genomic Aberrations in an African American colorectal Cancer Cohort Reveals a MSI-Specific Profile and Chromosome X Amplification in Male Patients. PLoS ONE, 7, e40392. https://doi.org/10.1371/journal.pone.0040392 